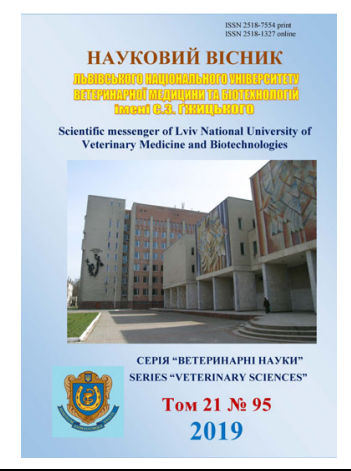

\author{
Науковий вісник Иьвівського національного університету \\ ветеринарної медицини та біотехнологій імені С.3. Гжицького. \\ Серія: Ветеринарні науки \\ Scientific Messenger of Lviv National University \\ of Veterinary Medicine and Biotechnologies. \\ Series: Veterinary sciences
}

\title{
The effect of sulfur compounds on the content of microelements in tissue organism rabbits
}

\author{
A.Z. Dychok-Nedzelska, Ya.V. Lesyk, I.I. Kovalchuk \\ Institute of Animal Biology, NAAS, Lviv, Ukraine
}

Article info

Received 26.09.2019

Received in revised form 24.10.2019

Accepted 25.10.2019

Institute of Animal Biology of NAAS, V. Stusa Str., 38, Lviv, 79000, Ukraine.

Tel.: +380-32-260-07-95

E-mail:anna1990vet@ukr.net
Dychok-Nedzelska A.Z., Lesyk Ya.V., \& Kovalchuk I.I. (2019). The effect of sulfur compounds on the content of microelements in tissue organism rabbits. Scientific Messenger of Lviv National University of Veterinary Medicine and Biotechnologies. Series: Veterinary sciences, 21(95), 161165. doi: $10.32718 /$ nvlvet 9530

The aim of the study was to investigate the effect of nanotechnology and sodium sulfate on the content of mineral elements in the tissues of 110-day-old rabbits by feeding different amounts of nano sulfur citrate. Studies were conducted on young rabbits of the Hyla breed in the private sector. Rabbits for the study were selected at the age of 41 days on the principle of analogues, weighing 1.2-1.4 kg, were divided into six groups (control and five experimental), 6 animals (3 males and 3 females) in each. Animals were kept in rooms with adjustable microclimate and illumination in mesh cages measuring $50 \times 120 \times 30 \mathrm{~cm}$, in accordance with modern animal health standards. The rabbits of the control group were fed without restriction a balanced granular compound feed, with free access to water. Animals of the first (I), second (II), third (III), and fourth (IV) experimental groups were fed a control group diet and fed with nano sulfur citrate for 2; 4; 8 and $12 \mathrm{mg} \mathrm{S} / \mathrm{kg}$ body weight. A solution of nano sulfur citrate $\left(1.0 \mathrm{~g} / \mathrm{dm}^{3}, \mathrm{pH} 1.38\right)$ was obtained from the Nanomaterials and Nanotechnologies LLC, Kyiv. The young of the fifth (V) experimental group was fed with a diet of the control group and water was given sodium sulfate $\left(\mathrm{Na}_{2} \mathrm{SO}_{4}\right)$ in the amount of $40 \mathrm{mg} \mathrm{S} / \mathrm{kg}$ body weight. At the $58^{\text {th }}$ day from the beginning of the experiment, the animals were slaughtered, taking into account the generally accepted bioethical norms of international regulations regarding the experimental work with vertebrate animals. Blood, tissues: liver, skin and wool were selected for the study. For determination of macro and microelements, the samples were pre-mineralized by dry aching method. After ashes, acid extraction was performed. In the prepared samples, the elements were determined by atomic absorption spectrophotometry using AAS-115 C. The digital data were statistically processed using the Student's $t$ test. Studies have found that the feeding of rabbit sulfur citrate in the smallest amount tested $2 \mathrm{mg} / \mathrm{kg}$ caused a significant increase in liver $-\mathrm{Fe}(P<0.05)$ and skin $-\mathrm{Zn}(P<0.05)$, whereas a larger dose of $4 \mathrm{mg} / \mathrm{kg}$ was affected by changes in blood $\mathrm{Cr}$ and $\mathrm{Fe}(P<0.01)$, liver $-\mathrm{Zn}$ and $\mathrm{Fe}(P<0.05)$, skin $-\mathrm{Zn}(P<0.01)$, wool $-\mathrm{Zn}$ and $\mathrm{Fe}(P<0.05)$ compared to the control group. It was noted that the use in the diet of rabbits supplements of sulfur citrate at the rate of $8 \mathrm{mg} / \mathrm{kg}$ was marked by the greatest changes in the investigated tissues of the rabbit body, in particular the higher blood levels of $\mathrm{Cr}(P<0,001), \mathrm{Fe}(P<0,05)$ and $\mathrm{Cu}$ $(P<0.01)$, liver $-\mathrm{Zn}, \mathrm{Fe}$ and $\mathrm{Cu}(P<0.05)$, skin $-\mathrm{Zn}(P<0.001)$, higher amounts of $12 \mathrm{mg} / \mathrm{kg}$ caused changes in liver content $-\mathrm{Zn}(P<0.01)$ and $\mathrm{Fe}(P<0.05)$, skin $-Z n(P<0.05)$ compared to the control, indicating the stimulating effect of the organic sulfur compound on the activation of the processes of assimilation of these elements in their body. The use of sodium sulfate in the amount of $40 \mathrm{mg} \mathrm{S} / \mathrm{kg}$ body weight was less likely to affect the content of the studied mineral elements compared with the control group with a more pronounced effect: $\mathrm{Zn}$ in the liver and skin, $\mathrm{Cr}$ in wool. Therefore, feeding in the diet of rabbits II and III experimental groups of nano sulfur citrate in the amount of 4 and $85 / \mathrm{kg}$ body weight was more pronounced synergistic effect on the trace elements in the tissues of their body than the use of inorganic compounds and the control group.

Key words: rabbit, nano sulfur citrate, sodium sulfate, blood, liver, skin, wool, trace elements. 


\title{
Вплив сполук сульфуру на вміст мікроелементів у тканинах організму кролів
}

\author{
А.З. Дичок-Недзєльська, Я.В. Лесик, І.І. Ковальчук
}

Інститут біології тварин НААН, м. Львів, Україна

\begin{abstract}
Метою дослідження було з'ясувати вплив випоювання різних кількостей иитрату сульфуру, отриманого методом нанотехнології, та сульфату натрію на вміст мінеральних елементів у тканинах організму кролів 110-добового віку. Дослідження проводили на молодняку кролів породи Hуlа в умовах приватного господарства. Кролів для дослідження відбирали у віџі 41 доби за принципом аналогів, масою тіла 1,2-1,4 кг, поділяли на шість груп (контрольну і п'ять дослідних) по 6 тварин (3 самиі і 3 самииі) у кожній. Тварин утримували в приміщеннях із регульованим мікрокліматом та освітленням у сітчастих клітках розміром $50 \times 120 \times 30$ см, відповідно до сучасних ветеринарно-санітарних норм. Кролям контрольної групи згодовували без обмеження збалансований гранульований комбікорм, з вільним доступом до води. Тваринам першої (I), другої (II), третьої (III) і четвертої (IV) дослідних груп згодовували корми раціону контрольної групи і впродовж доби випоювали сульфуру цитрат з розрахунку відповідно 2; 4; 8 і 12 мг


лодняку n'ятої (V) дослідної групи згодовували корми раціону контрольної групи $i$ з водою задавали сульфат натрію (Na2 $\left.\mathrm{SO}_{4}\right)$ в кількості 40 мг S/кг маси тіла. На 58 добу від початку експерименту тварин забивали із врахуванням загальноприйнятих біоетичних норм міжнародних положень стосовно проведення експериментальних робіт із хребетними тваринами. Для дослідження відбирали кров, тканини: печінки, шкіри та шерсті. Для визначення макро-і мікроелементів зразки попередньо мінералізували методом сухого озолення. Після озолення проводили кислотну екстракиію. У підготовлених зразках визначали елементи методом атомно-абсорбиійної спектрофотометрії, за допомогою ААС-115 С. Цифрові дані опраџьовували статистично з використанням t критерію Стьюдента. Дослідженнями встановлено, що випоювання кролям сульфуру цитрату у найменшій досліджуваній кількості 2 мг/кг викликало вірогідне збільшення у печінці - Fe $(P<0,05)$ і шкірі - Zn $(P<0,05)$, тимчасом як більша доза 4 мг/кг позначилася змінами у крові $\mathrm{Cr}$ і Fe $(P<0,01)$, печіниі - Zn і Fe $(P<0,05)$, шкірі $-\mathrm{Zn}(P<0,01)$, шерсті $-\mathrm{Zn}$ і Fe $(P<0,05)$ порівняно 3 контрольною групою. Відзначено, що застосування у раціоні кролів добавки сульфуру цитрату з розрахунку 8 мг/кг відзначилося найбільшими змінами у досліджсваних тканинах організму кролів, зокрема вищим рівнем у крові $\mathrm{Cr}(P<0,001), \mathrm{Fe}(P<0,05)$ і $\mathrm{Cu}$ $(P<0,01)$, печіниі - Zn, Fe i Cи $(P<0,05)$, икірі - Zn $(P<0,001)$, вищі кількості12 мг/кг викликало зміни вмісту в печінці - Zn $(P<0,01)$ i Fe $(P<0,05)$, шкірі - Zn $(P<0,05)$ порівняно з контролем, щяо свідчить про стимулювальний вплив органічної сполуки сульфуру на активацію процесів засвоєння ииих елементів в їхньому організмі. Використання сульфат натрію в кількості 40 мг $S / \kappa 2$ маси тіла позначилося меншим вірогідним впливом на вміст досліджуваних мінеральних елементів порівняно з контрольною групою з більш вираженим впливом: Zn у печінщі та шкірі, Сr у шерсті. Отже, випоювання у рачіоні кролів II $і$ III дослідних груп сульфуру цитрату в кількості 4 і 8 S/кг маси тіла позначилося більш вираженим синергічним впливом на досліджувані мікроелементи в тканинах їхнього організму, ніж використання неорганічної сполуки та контрольною групою.
\end{abstract}

Ключові слова: кролі, сульфуру циттрат, сульфат натрію, кров, печінка, икіра, шерсть, мікроелементи.

\section{Вступ}

Промислове ведення кролівництва передбачає постійний контроль раціонів за поживними та мінеральними речовинами для досягнення генетичного потенціалу сучасних порід та гібридів кролів. Мінеральний склад організму - одна 3 контрольованих констант, що пов'язана 3 його можливістю депонувати речовини і діяльністю органів, здатних збільшувати або зменшувати вміст мікро-і макроелементів. До органів, що депонують мінеральні речовини, відносяться кісткова тканина, шкіра, печінка, селезінка та інші (Mazurkevych, 2010). У кормах різних зон України дефіцит протеїну сягає 25-35\%, спостерігається i нестача багатьох макро-і мікроелементів, у тому числі й Сульфуру. Варто зазначити, що потреба у мінеральних речовинах для промислових порід кролів та їхніх гібридів вивчена недостатньо, про що свідчить низка публікацій (Andrews, 2000; Arthur, 2003). Відомо, що неорганічні сполуки Сульфуру засвоюються мікрофлорою кишечнику і активно включаються в органи і тканини тварин (Arthur, 2003). Сульфур в організмі тварин перебуває у складі КоА, сульфітованих полісахаридів, сульфгідрильних груп низки ензимів, сірчаної кислоти (Shoveller et al., 2005). Тому незначна кількість неорганічного сульфуру, що засвоюється організмом з корму, не завжди забезпечує необхідний рівень обміну речовин організму, особливо це стосується промислових порід та гібридів кролів (Burrin \& Stoll, 2007). Ступінь засвоєння сульфуру визначаться рівнем протеїнового і енергетичного живлення та здійснюється за допомогою механізмів активного транспорту (Jefimov, 2008). В промисловому кролівництві особливо важливо підгодовувати кролів сульфурвмісними препаратами, оскільки мікроклімат закритого приміщення негативно впливає на перебіг сезонної і вікової линьки та якість шкурок (Kravchenko \& Mel'nyk, 2015). Вміст Сульфуру в організмі становить 0,16-0,23\% від маси тіла, з яких близько половини знаходиться у м'язовій тканині. 3 віком його концентрація збільшується, що можливо пов'язано 3 посиленням біосинтезу м'язового протеїну та накопиченням цього елемента у шерсті та пір'ї (Burrin \& Stoll, 2007). Біологічна ефективність використання мінеральних речовин в організмі, їх вибір визначаються фізіологічною роллю конкретного елемента, їхнім синергізмом або антагонізмом, рівнем збалансованості раціонів за поживністю та біологічно активними речовинами в процесі травлення (Pogorjelov et al., 2010; Mazurkevych, 2010; Chekman, 2011). Важливим $є$ не тільки контроль кількості мінеральних елементів у раціоні, а й їхня біодоступність (Afolabi et al., 2010). Зважаючи на вищевказане, значний науковий інтерес мають органічні комплекси S. Тому метою 
дослідження було вивчити вплив випоювання сульфуру цитрату, отриманого методом нанотехнології, та сульфату натрію на вміст мінеральних речовин у тканинах їхнього організму на 110 добу життя.

\section{Матеріал і методи досліджень}

Дослідження проводили на молодняку кролів породи Hyla у ТзОВ “Горлиця” с. Добряни Городоцького району Львівської області, поділених на шість груп (контрольну і п'ять дослідних), по 6 тварин у кожній, підібраних за принципом аналогів у віці 50 діб. Тварин утримували в приміщеннях 3 регульованим мікрокліматом та освітленням у сітчастих клітках розміром $50 \times 120 \times 30$ см, відповідно до сучасних ветеринарно-санітарних норм (Chudley \& Greeno, 2010). Кролям контрольної групи згодовували вволю збалансований гранульований комбікорм 3 вільним доступом до води. Тваринам першої (I), другої (II), третьої (III) i четвертої (IV) дослідних груп згодовували корми раціону контрольної групи і впродовж доби випоювали сульфуру цитрат з розрахунку відповідно 2; 4; 8 і 12 мг S/кг маси тіла. Розчин наносульфуру цитрату $\left(1,0\right.$ г/дм $\left.{ }^{3}, \mathrm{pH} 1,38\right)$ отримано від ТзОВ "Наноматеріали і нанотехнологіï”, м. Київ (Kosinov \& Kaplunenko, 2009). Молодняку п’ятої (V) дослідної групи згодовували корми раціону контрольної групи і з водою задавали сульфат натрію $\left(\mathrm{Na}_{2} \mathrm{SO}_{4}\right)$ в кількості 40 мг $\mathrm{S} /$ кг маси тіла. Дослід тривав 68 діб, в тому числі підготовчий період 10 діб, дослідний - 58 діб. На 58 добу від початку експерименту тварин забивали із врахуванням загальноприйнятих біоетичних норм міжнародних положень стосовно проведення експериментальних робіт із хребетними тваринами (Official Journal of the European Union L276/33, 2010). Для дослідження відбирали кров, тканини: печінки, шкіри та шерсті. Для визначення макро- та мікроелементів зразки попередньо мінералізували методом сухого озолення. Після озолення проводили кислотну екстракцію. У підготовлених зразках визначали елементи методом атомно-абсорбційної спектрофотометрії за допомогою ААC-115 С. Цифрові дані опрацьовували статистично 3 використанням $\mathrm{t}$ критерію Стьюдента. Розраховували середні арифметичні величини (М) та похибки середніх арифметичних величин $( \pm \mathrm{m})$. Зміни вважали вірогідними за $\mathrm{P}<0,05$. Для розрахунків використано комп'ютерну програму Excel.

\section{Результати та їх обговорення}

Картина крові є інформативним показником, що характеризує зміни в організмі. Визначення вмісту мікроелементів у крові засвідчило найбільше вірогідних змін за вмістом Хрому, Феруму і Куруму (табл.). Зокрема, у крові кролів II і III дослідних груп рівень Хрому та Феруму був відповідно вищим на 36,0 i $75,0 \%(\mathrm{P}<0,01-0,001)$ та 23,0 і 24,2\% ( $<<0,05-0,01)$ за тенденції до вищого вмісту цих елементів у інших групах порівняно з контролем. Концентрація Купруму в крові кролів III дослідної групи була вищою на
$64,6 \%$ (Р $<0,01)$, тимчасом як його рівень для інших груп становив вищі параметри, які за статистичним обрахунком не були вірогідними порівняно $з$ контрольною групою тварин. Дослідженнями крові відзначено синергічний вплив Сульфуру на вміст Хрому, Феруму та Купруму залежно від його застосованої кількості у кролів II і III дослідних груп, яким випоювали сульфуру цитрат у кількості 4 і 8 мг S/кг маси тіла. Ці елементи входять до складу ензимних систем, $\epsilon$ каталізаторами перекисного окиснення ліпідів, впливають на стан імунної системи, що може свідчити про активацію метаболізму в організмі кролів (Mazurkevych, 2010).

Відомо, що розподіл мінеральних елементів між тканинами та органами нерівномірний. Максимальні концентрації більшості елементів локалізуються у тканинах печінки. Тому цей орган вважається функціональним мікроелементним депо організму. Найбільше вірогідних змін у печінці відзначено за вмістом Цинку та Феруму. Так, у тканині печінки кролів II, III, IV i V дослідних груп рівень Цинку був відповідно вищим на 53,3; 34,0; 43,9 і 27,1\% (P < 0,05-0,01) порівняно $з$ контрольною групою. 3 літературних джерел відомо, що у процесі травлення Цинк потрапляє в кров і через ворітну вену надходить до печінки, а потім у системний кровообіг й переноситься до інших органів і тканин (Marcellini, 2007; Hunt, 2008), що може свідчити про активацію метаболізму в організмі кролів дослідних груп за винятком тварин, яким випоювали найменшу кількість Сульфуру цитрату. Відомо, що після всмоктування у травному каналі Ферум накопичується у печінці, селезінці та слизовій оболонці кишечнику у вигляді феритину. Результати дослідження вказують, що рівень Феруму в тканині печінки тварин I, II, III і IV був відповідно вірогідно вищим на 32,$2 ; 33,6 ; 33,4$ і 34,5\% (P < 0,05) порівняно 3 контролем. Це може свідчити про виражений позитивний вплив органічної сполуки Сульфуру порівняно 3 неорганічною на синтетичні процеси в організмі кролів, що сприяло активації процесів утворення та всмоктування з травного каналу Феруму. Рівень Купруму у кролів ІІІ дослідної груп був вірогідно вищим на $25,3 \%(\mathrm{P}<0,05)$ порівняно 3 контрольною групою, що може свідчити про дозозалежну особливість дії органічної сполуки Сульфуру.

Результати дослідження вмісту мікроелементів у шкірі вказують про виражений вплив сполук сульфуру на засвоєння Цинку в травному каналі, що позначилося вірогідним підвищенням його рівня у тканинах шкіри кролів. Так, концентрація Цинку у шкірі кролів I, II, III, IV i V дослідних груп порівняно з контролем була вищою на 47,4\% (P < 0,05), 46,6\% $(\mathrm{P}<0,01), 45,8 \%(\mathrm{P}<0,01), 42,2 \%, 40,7 \%(\mathrm{P}<0,05)$ відповідно. Фізіологічні кількості вмісту Цинку в організмі людини і тварин регулюється рівнем абсорбції та реабсорбції в кишечнику, а також екскрецією, яка здійснюється через видільну систему i шкіру (Andrews, 2000). За дефіциту Цинку розвиваються специфічні зміни в епідермісі, характерні для паракератозу, внаслідок порушеного синтезу клітинами 
шкіри кератогіаліну (Berestenko \& Stus', 2007). Відомо, що Цинк необхідний для нормального росту шерсті, кігтів і підтримки здорового стану шкіри. Будучи важливою частиною низки біологічно активних речовин, він обумовлює активність інсуліну, адреналіну, фолікуліну і тестостерону. Тому фізіологічні кількості Цинку є необхідним чинником для нормального функціонування організму швидкоростучих промислових порід та гібридів кролів.

\section{Таблиця}

Вміст мінеральних речовин у тканинах організму кролів за випоювання сполук Сульфуру, мг/кг сирої маси $(\mathrm{M} \pm \mathrm{m}, \mathrm{n}=6)$

\begin{tabular}{|c|c|c|c|c|c|c|}
\hline $\begin{array}{c}\text { Орган } \\
\text { /тканина }\end{array}$ & Група & $\mathrm{Co}$ & $\mathrm{Cr}$ & $\mathrm{Zn}$ & $\mathrm{Fe}$ & $\mathrm{Cu}$ \\
\hline \multirow{6}{*}{ Кров, мг/л } & $\mathrm{K}$ & $0,027 \pm 0,012$ & $0,036 \pm 0,003$ & $2,66 \pm 0,35$ & $410,8 \pm 26,69$ & $0,65 \pm 0,11$ \\
\hline & Д-I & $0,046 \pm 0,016$ & $0,044 \pm 0,004$ & $3,48 \pm 0,26$ & $465,3 \pm 17,39$ & $0,76 \pm 0,11$ \\
\hline & Д-II & $0,026 \pm 0,013$ & $0,049 \pm 0,003 * *$ & $2,69 \pm 0,38$ & $505,5 \pm 17,90 * *$ & $0,61 \pm 1,14$ \\
\hline & Д-III & $0,025 \pm 0,013$ & $0,063 \pm 0,005 * * *$ & $2,95 \pm 0,22$ & $510,31 \pm 27,88^{*}$ & $1,07 \pm 0,11^{* *}$ \\
\hline & Д-IV & $0,021 \pm 0,004$ & $0,047 \pm 0,001$ & $2,86 \pm 0,26$ & $455,9 \pm 18,22$ & $0,72 \pm 0,16$ \\
\hline & Д-V & $0,012 \pm 0,002$ & $0,046 \pm 0,005$ & $2,97 \pm 0,23$ & $443,8 \pm 29,11$ & $0,77 \pm 0,12$ \\
\hline \multirow{6}{*}{ Печінка } & $\mathrm{K}$ & $0,025 \pm 0,004$ & $0,023 \pm 0,005$ & $30,98 \pm 1,36$ & $42,55 \pm 4,76$ & $3,79 \pm 0,82$ \\
\hline & Д-I & $0,035 \pm 0,004$ & $0,050 \pm 0,001$ & $34,54 \pm 3,61$ & $56,26 \pm 3,43^{*}$ & $6,29 \pm 1,32$ \\
\hline & Д-II & $0,035 \pm 0,006$ & $0,024 \pm 0,005$ & $47,51 \pm 7,09 *$ & $56,81 \pm 3,35^{*}$ & $5,47 \pm 1,13$ \\
\hline & Д-III & $0,034 \pm 0,005$ & $0,022 \pm 0,004$ & $43,27 \pm 4,46^{*}$ & $56,74 \pm 3,83 *$ & $8,54 \pm 1,89 *$ \\
\hline & Д-IV & $0,043 \pm 0,010$ & $0,044 \pm 0,002$ & $46,60 \pm 4,10^{* *}$ & $57,20 \pm 3,38^{*}$ & $7,38 \pm 1,51$ \\
\hline & Д-V & $0,032 \pm 0,005$ & $0,039 \pm 0,008$ & $39,35 \pm 2,89 *$ & $47,57 \pm 5,70$ & $5,07 \pm 0,85$ \\
\hline \multirow{6}{*}{ Шкіра } & $\mathrm{K}$ & $0,038 \pm 0,006$ & $0,043 \pm 0,005$ & $25,31 \pm 2,91$ & $15,18 \pm 1,25$ & $2,76 \pm 0,64$ \\
\hline & Д-I & $0,043 \pm 0,007$ & $0,048 \pm 0,002$ & $37,33 \pm 4,10^{*}$ & $14,85 \pm 0,71$ & $2,54 \pm 0,64$ \\
\hline & Д-II & $0,035 \pm 0,003$ & $0,054 \pm 0,003$ & $37,16 \pm 1,94 * *$ & $15,21 \pm 0,91$ & $2,21 \pm 0,40$ \\
\hline & Д-III & $0,050 \pm 0,007$ & $0,051 \pm 0,006$ & $36,95 \pm 2,67 * * *$ & $14,28 \pm 0,87$ & $2,72 \pm 0,42$ \\
\hline & Д-IV & $0,044 \pm 0,006$ & $0,049 \pm 0,005$ & $36,08 \pm 3,05 *$ & $13,04 \pm 0,78$ & $3,03 \pm 0,29$ \\
\hline & Д-V & $0,050 \pm 0,007$ & $0,045 \pm 0,003$ & $35,66 \pm 3,17^{*}$ & $11,89 \pm 1,13$ & $2,47 \pm 0,46$ \\
\hline \multirow{6}{*}{ Шерсть } & $\mathrm{K}$ & $0,055 \pm 0,010$ & $0,037 \pm 0,004$ & $16,12 \pm 1,28$ & $12,30 \pm 0,76$ & $8,26 \pm 0,84$ \\
\hline & Д-I & $0,055 \pm 0,007$ & $0,059 \pm 0,007^{*}$ & $18,97 \pm 0,42$ & $14,17 \pm 1,09$ & $8,57 \pm 0,43$ \\
\hline & Д-II & $0,053 \pm 0,003$ & $0,049 \pm 0,004$ & $19,70 \pm 0,71 *$ & $16,16 \pm 1,21 *$ & $8,93 \pm 0,89$ \\
\hline & Д-III & $0,069 \pm 0,007$ & $0,056 \pm 0,012$ & $18,56 \pm 0,63$ & $14,99 \pm 0,95$ & $10,13 \pm 1,51$ \\
\hline & Д-IV & $0,067 \pm 0,010$ & $0,071 \pm 0,008^{*}$ & $17,08 \pm 0,90$ & $14,60 \pm 1,34$ & $8,58 \pm 0,92$ \\
\hline & Д-V & $0,061 \pm 0,012$ & $0,070 \pm 0,005^{*}$ & $17,51 \pm 1,44$ & $15,08 \pm 1,56$ & $8,93 \pm 0,61$ \\
\hline
\end{tabular}

Примітка: тут і далі *-P $<0,05 ; * *-\mathrm{P}<0,01, * * *-\mathrm{P}<0,001$ порівняно 3 контрольною группою

Шерсть містить значну кількість мінеральних елементів і $\epsilon$ додатковим шляхом їхнього виведення 3 організму. У певних випадках доцільним є визначення вмісту окремих мінеральних речовин у шерсті та рогових утвореннях, що показує забезпеченість організму протягом тривалого періоду, адже оновлення цих структур, на відміну від крові, відбувається достатньо повільно. У шерсті кролів вміст Хрому в I і IV, V дослідних групах на 59,4\% (P < 0,05), 91,8\% (P<0,05) та $89,1 \%$ (P < 0,05), відповідно був вірогідно вищим порівняно $з$ контролем. Рівень Цинку та Феруму в шерсті кролів II дослідної групи був вірогідно вищим на 22,2\% (P < 0,05) і 31,3\% (P < 0,05) порівняно з контрольною групою.

Випоювання кролям після відлучення органічної та неорганічної сполук Сульфуру позначилося вірогідними змінами вмісту $\mathrm{Cr}, \mathrm{Zn}, \mathrm{Fe}$ i $\mathrm{Cu}$ у тканинах крові, печінки, шкіри та шерсті, що може свідчити про виражений дозозалежний синергічний вплив цитрату сульфуру, ніж сульфату натрію на засвоєння та метаболізм цих елементів в організмі кролів.

\section{Висновки}

1. Випоювання кролям сульфуру цитрату у найменшій кількості 2 мг/кг викликало вірогідне

збільшення у печінці - Fe $(\mathrm{P}<0,05)$ та шкірі - Zn $(\mathrm{P}<0,05)$, тимчасом як більша доза 4 мг/кг позначилася змінами у крові $\mathrm{Cr}$ i $\mathrm{Fe}(\mathrm{P}<0,01)$, печінці $-\mathrm{Zn}$ i Fe $(\mathrm{P}<0,05)$, шкірі - Zn $(\mathrm{P}<0,01)$, шерсті - Zn i Fe $(\mathrm{P}<0,05)$ порівняно з контрольною групою.

2. Застосування у раціоні кролів добавки сульфуру цитрату 3 розрахунку 8 мг/кг відзначилося вищим рівнем у крові $\mathrm{Cr}(\mathrm{P}<0,001)$, Fe $(\mathrm{P}<0,05)$ i $\mathrm{Cu}$ $(\mathrm{P}<0,01)$, печінці - Zn, Fe і Cu $(\mathrm{P}<0,05)$, шкірі $-\mathrm{Zn}$ ( $\mathrm{P}<0,001)$, вищі кількості12 мг/кг викликало зміни вмісту в печінці - Zn (P $<0,01)$ і Fe $(\mathrm{P}<0,05)$, шкірі $\mathrm{Zn}(\mathrm{P}<0,05)$ порівняно з контролем.

3. Використання неорганічної сполуки сульфуру (сульфат натрію в кількості 40 мг $\mathrm{S} /$ кг маси тіла) позначилося меншим вірогідним впливом на вміст досліджуваних мінеральних елементів порівняно з контрольною групою 3 більше вираженим впливом: Zn у печінці та шкірі, Cr у шерсті. 


\section{References}

Afolabi, K.D., Akinsoyinii, A.O., Olajide, R., \& Akinleye, S.B. (2010). Haematological parameters of the Nigerian local grower chickens fed varying dietary levels of palm kernel cake. Proc. of the $35^{\text {th }}$ Annual Conf. of the Nig. Soc. for Anim. Prod, 247. https://hrcak.srce.hr/69549.

Andrews, G.K. (2000). Regulation of metallothionein gene expression by oxidative stress and metal ions. Biochem Pharmacol, 59(1), 95-104. doi: 10.1016/s0006-2952(99)00301-91.

Arthur, J.R. (2003). Selenium supplementation: does soil supplementation help and why? Proceedings of the Nutrition Society, 62(2), 393-397. doi: 10.1079/pns2003254.

Berestenko, S.V., \& Stus', V.P. (2007). Mikrojelementy v medicine, 8(3), 1-12 (in Russian).

Burrin, D.G., \& Stoll, B. (2007). Emerging aspects of gut sulfur amino acid metabolism. Curr. Opin. Clin. Nutr. Metab. Care, 10(1), 63-68. doi: 10.1097/MCO. 0b013e3280115d36.

Chekman, I.S. (2011). Nanofarmakologija: Pidruchnyk. K. (in Ukrainian).

Chudley, R., \& Greeno, R. (2010). Building Construction Handbook. 8th ed. Elsevier Ltd. https://trove.nla.gov.au/work/7941755.

De Blas, C., \& Wiseman, J. (2010). Nutrition of the Rabbit. 2nd Edition. Library of Congress Cataloging-inPublication Data. http://wabbitwiki.com/images/7/7d/ Nutrition.of.the.Rabbit.2ed-deBlas.Wiseman.pdf

Harkness, J.E., Turner, P.V., \& VandeWoude, S. (2013). Haematology, clinical chemistry, and urinalysis. In: Biology and medicine of rabbits and rodents. 5th ed. Ames, IA, Wiley, 116-131.
Hunt, J.R. (2008). Adaptation in human zinc absorption as influenced by dietary zinc and bioavailability. The American Journal of Clinical Nutrition, 87(5), 13361345. doi: 10.1093/ajen/87.5.1336.

Jefimov, V.G. (2008). Obmin mineralnych rechovyn v normi ta pry patologii. Tekst lekcii' Dnipropetrovs'k, 45 (in Ukrainian).

Kosinov, M.V., \& Kaplunenko, V.G. (2009). Patent of Ukraine for Utility Model No. 38391. IPC (2006): C07C 51/41, C07F 5/00, C07F 15/00, C07C 53/126 (2008.01), C07C 53/10 (2008.01), A23L 1/00, B82B3/00. Method of obtaining metal carboxylates. Nanotechnology for the production of metal carboxylates. Publ. Jan 12, 2009 Bull No. 1/2009.

Kravchenko, O.O., \& Mel'nyk, V.O. (2015). Technologoja ta bezpeka godivli hutrovyh zviriv, kroliv, sobak. Mykolai'v, 27-32 (in Ukrainian).

Marcellini, F. (2007). Psychosocial and biochemical interactions in aging: preliminary results from an Italian old sample of "Zincage" project. Arch Gerontol Geriatr, 44(1). 259-269. doi: 10.1016/j.archger.2007.01.035.

Mazurkevych, A.I. (2010). Fiziologija tvaryn. Pidruchnyk dlja VNZ I-IV r.a. 232-239 (in Ukrainian).

Official Journal of the European Union L276/33. (2010). Directive 2010/63/EU of The European Parliament and of The Council of 22 September 2010 on the protection of animals used for scientific purposes. 86/609/EC. 20.10.2010.

Pogorjelov, M.V., Bumejster, V.I., Tkach, G.F., Bonchev, S.D., Suhodub, L.F., \& Danyl'chenko, S.M. (2010). Mikro ta makroelementy (obmin, patologija ta metody vyznachennja). Monografija. Vydavnyctvo SumDU, 223-239 (in Ukrainian).

Shoveller, A.K., Stoll, B., Ball, R.O., \& Burrin, D.G. (2005). Nutritional and functional importance of intestinal sulfur amino acid metabolism. J Nutr, 135(7), 1609-1612. doi: 10.1093/jn/135.7.1609. 